UCLA-449

Biology and Medicine

\author{
THE UNIVERSITY OF CALIFORNIA \\ Los Angeles Campus \\ SCHOOL OF MEDICINE \\ Department and Laboratories of \\ Nuclear Medicine and Radiation Biology \\ 10875 Le Conte Avenue. \\ Los Angeles 24, California \\ Contract No. AT(04-1)-GEN-12
}

\title{
DISCLAIMER
}

\begin{abstract}
This report was prepered as an account of work sponsored by an agency of the United States Government. Neithes the United States Government nor any agency thereof, nor any of their employees, makes any warranty, express or implied, or assumes any legal liability or responsibility for the accurac $r$, completeness, or usefulness of any information, apparatus, product, or process disclosed, or represents that its use would not infringe privately owned rights. Reference herein to any specific commercial product, process, or service by trade name, trademark, manufacturer, or otherwise does not necessarily constitute or imply its endorsement, recommendation, or favoriıg by the United States. Government or any agency thereof. The views and opinions of autliors expressed herein do not necessarily state or reflect those of the United States Government or any agency thereof.
\end{abstract}

\section{THE RADIOISOTOPE OSTEOGRAM - Kinetic Studies of Skeletal Disorders in Humans}

by

Norman S. MacDonald

October 16, 1959 


\section{LEGAL NOTICE}

This report was prepared as an account of Government sponsored work. Neither the United States, nor the Commission, nor any person acting on behalf of the commission:

A. Makes any warranty or representation, expressed or implied, with respect to the accuracy, completeness, or usefulness of the information contained in this report, or that the use of any information, apparatus, method, or process disclosed in this report may not infringe privately owned rights; or

B. Assumes any liabilities with respect to the use of, or for damages resulting from the use of any information, apparatus, method, or process disclosed in this report.

As used in the above, "person acting on behalf of the Commission" includes any employee or contractor of the Commission, or employee of such contractor, to the extent that such employee or contractor of the Commission, or employee of such contractor prepares, disseminates, or provides access to, any information pursuant to his employment or contract with the Commission, or his employment with such contractor. 


\section{IDISCLAIMER}

Portions of this document may be illegible in electronic innage products. Images are produced from the best available original document. 
TABLE OF CONTENTS

Page No.

\begin{abstract}
\end{abstract}
4

INTRODUCTION

MATERIALS AND METHODS

RESULTS

DISCUSSION

12

SUMMARY

22

ACKNOWLEDGEMENTS

23

TABLE I

24

TABLE II

25

TABLE III

26

TABLE IV

27

FIGURE 1

FIGURE 2

29

FIGURE 3

FIGURE 4 31

FIGURE 5

32

REFERENCES 


\section{ABSTRACT}

Radioactive strontium can serve as a tracer to gain information concerning calcium metabolism in human subjects. Gamma-emitting

$\mathrm{Sr}^{85}$ is used rather than the much more hazardous, beta-emitting $\mathrm{Sr}^{89}$ and $\mathrm{Sr}^{90} \cdot\left(\mathrm{Ca}^{47}\right.$ - the ideal tracer for normal calcium - is quite expensive and difficult to procure.) Very significant information may be obtained merely by measuring and recording the changes in radioactivity in various body areas during the first hour after intravenous injection of the bone-seeking radioisotope. This is accomplished by placing a lead-shielded gamma-scintillation detector in contact with the skin over the sites of interest and recording the activities on a scaler or ratemeter. The activity versus time curves so obtained are called radioisotope osteograms. Data were presented which indicated that $\mathrm{Sr}^{85}$ osteograms for patients afflicted with osteoporosis, Paget's disease, tumor metastases to bone, and possibly multiple myeloma, differ significantly from those obtained from subjects with no skeletal abnormalities. Some interpretations of these deviations were discussed. The value of conducting double-tracer tests (e.g. $-\mathrm{Sr}^{85}$ plus radioiodinated serum albumin) was demonstrated, and correlations with excretion data were made. With further refinements the technique may ultimately become useful for certain diagnostic problems in the clinic and for evaluating the efficacy of treatment of these disorders. 
THE RADIOISOTOPE OSTEOGRAMKINETIC STUDIES OF SKELETAL DISORDERS IN HUMANS*

During the last fifteen years there has been a dramatic increase in the intensity of experimental research devoted to bone, as a tissue. In the United States a number of research programs encompassing broad studies of bone physiology have been developed and supported by the Atomic Energy Comımission.

One important factor in the heightened interest in bone metabolism is, of course, the quite justifiable concern over the effects of the increased amounts of radioactive materials now entering the food supplies of human populations. Certain of these radioisotopes, notably $\mathrm{Sr}^{90}$, are readily absorbed and deposited in the bony tissues. There is still another factor behind this rapid growth of interest in . bone physiology -- the influence of Franklin C. McLean. His many important contributions to the scientific literature are a matter of record, but in addition to this, his untiring, behind-the-scenes efforts to initiate and support symposia, conferences, and lectures dealing with bone physiology have been of great value in stimulating the advances in this field.

* This report is to be published in a special issue of CLINICAL ORTHOPEDICS as part of a collection of invited papers on the skeletal system, as sembled and dedicated in honor of Dr. Franklin C. McLean of the University of Chicago on the occasion of his seventy-second birthday. 
Out of the huge volume of experimental observations dealing with the biological behavior of potentially hazardous radioactive "bone-seekers" such as radium and $\mathrm{Sr}^{90}$, a number of fairly wellestablished principles have emerged. By suitable application of these, it is feasible to use radioactive elements as "tags" or "tracers" for investigating the normal constituents of tissues.

The recent developments of scintillation counters for gamma rays has made it possible to measure changes in radioactivity within the body by using collimated detectors held near the skin and pointed at various parts of interest. Data of this sort give information which often is unobtainable from assays of daily excreta. Unfortunately, the low penetrating power of the beta rays of $\mathrm{Ca}^{45}$ make it unsuitable for measurement by detectors placed outside the body. Furthermore, the beta-gamma emitting isotope $\mathrm{Ca}^{47}$ is exceedingly expensive and difficult to procure. However, radiostrontium can be used as a tag for the study of bone calcium. Admittedly, strontium is not a perfect atom for this purpose -- qualitatively, its absorption transport, $_{\text {, }}$ deposition, and excretory patterns are quite similar to those of calcium, but quantitative differences do exist and must be taken into account. $(1-4)$ The value of this technique of "body surface counting" of injected $\mathrm{Sr}^{85}$ and $\mathrm{Ca}^{47}$ has been clearly demonstrated by Bauer and others in several clinical studies of skeletal disorders. $(5,6)$ 
However, relatively little emphasis has been laid on studying and utilizing the events which occur immediately following the entry of the bone-seeking radioactivity into the blood. Laboratory experiments with animals have indicated that important information regarding osseous tissue can be secured by recording, more or less continuously, the variations of radioactivity in body areas during the first hour after injection of bone-seeking radioisotopes and supplementary tracers, such as radiosodium and radioiodine. These graphic records were called radioisotope osteograms. ${ }^{(7)}$ It is the purpose of this paper to present an account of our first attempt to apply the osteogram technique to human subjects。

\section{MATERIALS AND METHODS}

Carrier-free $\mathrm{Sr}^{85}$ was purchased from the Nuclear Science and Engineering Corporation, radioiodinated serum albumin (RISA) from Abbott Laboratories. Sterile, saline solutions of these materials were prepared. Doses ranged from 5-15 microcuries and were administered by direct injection into an antecubital vein.

The basic equipment consisted of a lead shielded, collimated, gamma scintillation probe with a $1 \frac{1}{2} " \times 1 "$ sodium iodide crystal, photomultiplier tube and preamplifier whose output was fed to a scaler. The detector was mourted on a counterbalanced, adjustable stand which 
could be brought to the patient's bedside. The usual procedure was to place an indelible ink mark on the surface of the skin over the area of interest. Several such spots were chosen, $e_{\circ} g_{\circ}$, temple, one or more vertebral bodies, knee, midshaft of a tibia, or a site of obvious skeletal pathology. Background counts were obtained with the detector touching the skin at each of the marked positions, after which the injection was delivered into a vein. A count of one minute duration was immediately taken at one of the chosen sites and recorded; the scaler was then reset and the detector aligned over the next site. This operation required less than one minute. A one minute count was taken, recorded and the detector moved to the next site. After all sites had been counted in this manner the whole sequence was repeated several times. Thus, the raw data for the osteogram consisted of observed activity (counts per minute) at each area, as a function of time postinjection. In a few cases these observations were continued for as long as two hours. When a continuous record was desired, with the detector fixed in one position, the scaler was replaced by a counting ratemeter and a strip-chart recorder. When it was possible, the patient was returned to approximately the same reclining position at intervals of 24 hours, for post-osteogram monitoring of the marked areas. Unfortunately, this could seldom be arranged, since most subjects were out-patients or left the hospital soon after the test. 
Three subjects were in the Metabolic Ward (Medical Center, UCLA) so that balance data on calcium, phosphorous and nitrogen were available. For these patients it was possible to obtain consecutive values for the total 24 hour urinary and stool output of the administered $\mathrm{Sr}^{85}$, as well as for a few serum samples. All such samples were assayed for radioactivity by counting suitable aliquots in a stationary scintillation counter equipped with a single-channel pulse height analyser. Activities were expressed as percentage of administered dose by comparing them with the counts observed the same day in aliquots of the dose stock solution, prepared so as to present the same geometry to the detector.

The earlier work with rabbits bearing tibial fractures ${ }^{(7)}$ had showed the usefulness of observing the behavior of radioiodinated serum albumin (RISA) in conjunction with the $\mathrm{Sr}^{85}$ osteogram. When the present clinical studies were undertaken, adequate dual-channel gamma spectrometer equipment was not available, so that in the several dual-tracer studies performed, it was necessary to inject the RISA first. The activity of the protein-bound $\mathrm{I}^{131}$ at the various sites was then measured at repeated one minute intervals as described above. After the counting rates had become constant (usually within 10 minutes) $\mathrm{Sr}^{85}$ was injected and the replicate counting procedure was carried out again. $\mathrm{The}^{85}$ activity for each individual 
measurement was obtained by subtracting the counts per minute due to RISA from the observed total counts per minute. In future work a two-channel gamma spectrometer will make it possible to count $\mathrm{Sr}^{85}$ and $\mathrm{I}^{131}$ simultaneously, after injection of a mixture of two radioisotopes。

\section{RESULTS}

Figure 1 gives the osteogram for tibia midshaft, temple and knee obtained from an injection of $5 \mu \mathrm{c}$ of $\mathrm{Sr}^{85}$ administered to a "normal", 24 year old, white female with no known disturbance of skeletal structure or metabolism. In describing such curves, it is convenient to refer to the time at which maximum radioactivity was observed。In Figure 1, for example, $T$ max was about 15 minutes for the tibia midshaft position of the detector, 6 minutes for temporal area and more than 41 minutes when the spongiosa of the knee was in the "field of view" of the broadly collimated detector . It is useful also to make rough comparisons between the various activities measured. Thus, the $\mathrm{Sr}^{85}$ in the blood, soft tissue and bone in the field of view of the detector, when directed at the temple, gave about three times the maximum counting rate observed when the detector was placed over the tibia midshaft area. Interpretation of these relationships will be discussed later. 
Figure 2 illustrates the RISA-osteograms and the $\mathrm{Sr}^{85}$-osteograms for a male patient suffering from multiple myeloma。 By separately counting the syringes containing the RISA and the $\mathrm{Sr}^{85}$, when inserted into a plastic phantom, before and again after the injections, a rough approximation of the relative counting rates of $\mathrm{I}^{131}$ and $\mathrm{Sr}^{85}$ actually given to the patient can be made. This value is used to estimate the levels of gross counts per minute ( $\mathrm{I}^{131}$ plus $\left.\mathrm{Sr}^{85}\right)$ which would be expected if the $\mathrm{Sr}^{85}$ were to behave exactly like RISA in the body. The dotted lines represent these calculated anticipated levels. An index of the difference between the behavior of $\mathrm{Sr}^{85}$ and RISA can be obtained by computing the ratio

$\left(\frac{c / m \text { of } \mathrm{Sr}^{85}}{\mathrm{c} / \mathrm{m} \text { of } \mathrm{RISA}}\right)$ at body site $\div\left(\frac{\mathrm{c} / \mathrm{m} \text { of } \mathrm{Sr}^{85}}{\mathrm{c} / \mathrm{m} \text { of } \mathrm{RISA}}\right)$ in dose.

When this index is greater than 1.0, more $\mathrm{Sr}^{85}$ has accumulated at the site under investigation than would have been predicted merely on the basis of tagged blood volume in that site.

Table I presents some values for the times required for attainment of maximum activity at various body sites in a number of subjects. For those cases where RISA was also administered, the accumulation index, $A$, is also given.

Table II illustrates the magnitude of $\mathrm{Sr}^{85}$ activity measured by the detector, when "aimed" at various body sites - relative to the 
activity of the mid-tibial area expressed as unity. This comparison was made at $30-45$ minutes after the $\mathrm{Sr}^{85}$ injection. However, it should be emphasized that the shape or trend of the osteogram record is its most important feature. The changes of radioactivity with the passage of time are of greater significance than any single measurement taken at some arbitrary time after the injection. Furthermore, it is futile to attempt to express the radioactivity observed by the detector in terms of "per cent of dose" or of absolute activity (disintegrations per minute) because the factors of geometry and scattering are unknown -- and, indeed, vary from one position over the body to another.

\section{DISCUSSION}

Interpretation of the Osteogram: The volume of tissue which is "seen" by the collimated detector comprises skin, blood, lymph, muscle and other soft tissue, bone and marrow. Therefore, changes in the total observed radioisotope activity with the passage of time reflect progressive changes of the amounts of radioisotope residing in each of these tissue categories. At these early times following the injection it is manifestly impossible to state with confidence what fraction of the $\mathrm{Sr}^{85}$ activity observed at any chosen moment is due to $\mathrm{Sr}^{85}$ in blood, what fraction is in soft tissues and what portion is 
deposited in bone. Some attempts to attack this problem by double tracer experiments on rabbits, using $\mathrm{Sr}^{85}$ in conjunction with $\mathrm{Cr}^{51}$ tagged red cells, diffusible ions such as $\mathrm{Na}^{22}$ and nondiffusible, tagged serum albumin have been reported ${ }^{(7)}$ It was concluded that the speed of mixing and transport of the injected radioisotope within the vascular network is rapid enough to ensure that the maximum concentration of $\mathrm{Sr}^{85}$ within these capillaries in a bone area is reached well within 8 minutes. This has been borne out in the clinical studies reported here - when RISA (which presumably cannot rapidly diffuse through the capillary walls into extravascular spaces) was administered intravenously, the counting rate always reached a maximum in less than 10 minutes, and usually in. about 5 minutes, after which it remained constant. In many situations however, (see Table I) maximum counting rates for $\mathrm{Sr}^{85}$ were reached only after many minutes or even many hours (e.g。 - knee activity increased for 24 hours in most cases). Therefore, the behavior of the $\mathrm{Sr}^{85}$ counting rate after the first 8-10 minutes is probably determined by what happens to the radioactive ions after they have been mixed thoroughly with the blood and transported to the area under the detector A large number of processes, of varying degrees of reversibility and quantitative importance, can be postulated as governing events in the fate of $\mathrm{Sr}^{85}$ ions during the first hour or so. Among these are diffusion or transport across the 
capillary membrane into extravascular fluids; transport into the interior of cortical bone via haversian canals and canaliculi; ionic exchange with an equal number of non-radioactive ions at the surfaces of bone mineral crystallites and possibly within crystal hydration layers; ${ }^{(8)}$ sequestration within the bulk of newly forming bone mineral during accretion or apposition of new bone ${ }^{(9)}$ and binding with components of soft tissue ${ }^{(3)}$ and the organic matrix of bone ${ }^{(10)}$ The results of this exploratory clinical study do not offer incontrovertible evidence elucidating the operation of any of these processes. However, the results do show that by radioisotope techniques it is possible to demonstrate serious deviation from their normal operation.

Osteoporosis: The osteograms of five patients with a diagnosis of osteoporosis differed from normals by exhibiting a distinctly more sluggish accumulation of $\mathrm{Sr}^{85}$ at sites comprised primarily of cortical bone (Table I). Thus, the detector aimed at mid-tibia region registered a slowly increasing counting rate during the whole examination which lasted at least 35 minutes -- with the six normal subjects, however, this area reached a maximum activity usually in less than 25 minutes and remained level. Experiments are currently under way to determine whether or not impaired circulation in senile, osteoporotic subjects plays a part in causing this effect. 
Paget's Disease: One patient with this malady was examined -a 46 year old female. The middle third of the left tibia was tender, swollen, bowed and hyperemic, but without severe pain. The right tibia seemed unaffected. Figure 3 shows the RISA and $\mathrm{Sr}^{85}$ osteograms. The left limb showed a higher level of RISA activity, reflecting the greater volume of blood coursing through this afflicted area. More significantly, $\mathrm{Sr}^{85}$ continued to accumulate in the affected segment throughout the duratior of the test, whereas the unaffected right tibia reached maximum activity in 10 minutes and remained at that level. What particular procesis in the welter of metabolic chains operating within this hyperactive area is responsible for this avid accumulation of the tracer strontium? The data offer no direct clue. One interesting possibility is that an extremely rapid turnover of calcium occurs in the lesion -- that is, abnormally large quantities of bone salts are being constantly resorjed and replaced by newly formed mineral, with little net gain or loss in bone density.

$$
\text { Multiple Myeloma: A rather complete study of } \mathrm{Sr}^{85}
$$

metabolism was carried out on one subject (F.H.) with a well established diagnosis of multiple myeloma. Over a period of six months, three separate injections of $\mathrm{Sr}^{85}$ were administered. The excretion data will be discussed in a later paragraph. The osteograms for tibia and knee did not differ sufficiently from our meager data for 
normals to warrant attachment of any significance (see Figure 2 and Tables I and II). However, the $\mathrm{Sr}^{85}$ activity registered when the detector was aimed at the temporal area decreased over a period of 30 minutes, after attaining its maximum value at 5-12 minutes postinjection. This early decrease was not observed in our series of normals. Roentgenograms of the patient's skull did show "punchedout" lesions, but with our very limited experience, it is impossible to say whether or not the temple osteograms truly reflected this pathological condition of the skull.

Metastases of Tumors: Bone seeking radioisotopes can be used to gain information to supplement roentgenogram findings. An example of this was provided by a 42 year old female with an infiltrating carcinoma of the right breast (biopsy). The $\mathrm{x}$-ray findings indicated osteoblastic lesions in the pelvis and humerus. The latter lesion appeared as a large, well-calcified body near the head of the right humerus. The left arm appeared normal。The patient lay supine, and $\mathrm{Sr}^{85}$ was injected into the left antecubital vein. Repeated counts were made with the detector placed alternately on each shoulder, directed vertically downward toward the head of the humerus. Figure 4 presents the results. The activity in the left shoulder was initially almost twice that in the right shoulder area, but fell rapidly and by 20 minutes matched it almost exactly. Why the activity in the 
left shoulder area followed this pattern during the first few minutes is not certain. It is possible that faulty injection may have deposited some of the isotope material into subcutaneous tissue in the left forearm. Relatively s.low absorption into the blood and transport toward the heart would bring steadily decreasing amounts of this radioactivity under the detector (when it was located over the left shoulder) before it was thoroughly mixed throughout the blood. Regardless of whether or not this is the correct explanation -- the important observation is that after 20 minutes the area encompassing the supposed osteoblastic lesion contained the same quantity of $\mathbf{S r}^{85}$ as the normal contralateral area. This equivalence was verified by five subsequent counts, the last of which was 20 days post-injection (see Figure 5). The most plausible conclusion is that the well calcified mass seen in the $x$-ray plate was not in a state of active calcification at the time of examination. There was not any great turnover of calcium nor any significant apposition or accretion of new calcium salts within the mass. This interpretation was supported to some extent when a search of the patient's records uncovered two roentgenograms taken six months and two years previously, In all three plates the calcified mass appeared to have the same density and dimensions.

One final example may be cited to suggest the potential utility 
of the osteogram technique. An 85 year old male, suffering from cancer of the prostate, was tested with RISA and $\mathrm{Sr}^{85}$. The $\mathrm{x}$-ray findings had indicated extensive osteoblastic metastases to bone, with bilateral involvement of the pelvis -- somewhat more pronounced on the right side. Replicate counting over the left and right ilium showed that tagged serum albumin reached maximum concentration in both sites within 4-5 minutes and remained constant. When $\mathrm{Sr}^{85}$ was injected, however, activity in the left iliac area was still increasing at the end of 25 minutes, whereas activity on the right side reached a maximum in 14 minutes and remained constant. These radioisotope findings suggest that metabolic activity involving calcium turnover was much greater on the left side of the pelvis than on the right.

Monitoring Data: Although the measurement of radiostrontium activities during the first hour after injection can yield very illuminating information regarding the broad features of calcium metabolism, the full picture can be seen only when retention and excretion data are also at hand. Retention of gamma-emitting radioactive isotopes within the body as a whole can be measured in "total body counters", two prototypes of which were developed at Argonne National Laboratory and Los Alamos Scientific Laboratory. Comparisons of the retentions by various parts of the body can be made by monitoring with a movable detector equipped with adequate shielding 
and collimation. Unfortunately, our data on the day-by-day variation in radioisotope activity in the bones of the patients tested to date are too fragmentary to per mit useful generalizations linking such measurements with specific skeletal disturbances. $\mathrm{Sr}^{85}$ activity in tibia shaft and skull begins to decline a few hours after injection. Areas containing spongiosa ou: localized spots of intense metabolic activity (healing fractures) continue to accumulate activity for 24 hours or more before declining. (Similar findings have already been reported by Bauer, Carlsson and Lindquist, who have amassed excretion and bone monitoring data on several hundred cases.) ${ }^{(11)}$ Figure 5 illustrates the sort of information obtained by monitoring measurements. One of the subjects (H-11) is the same patient discussed earlier, who had a calcified mass of: probable metastatic origin in the right shoulder. It is apparent that this pathologic mass has had little effect on the deposition and retention of $\mathrm{Sr}^{85}$ in the area and is, therefore, relatively inactive in terms of calcium metabolism.

It should be noted that, with the exception of the knee area for the first day or two, all the areas which were monitored lost $\mathrm{Sr}^{85}$ at a faster rate than the tibial midshaft. That is, for any given day, the ratio of shoulder activity/tibia activity was always less in magnitude than the ratio at one hour post-injection. This does not prove that these bone tissues lose $\mathrm{Sr}^{85}$ at a faster rate than tibial cortex 
(although this may very well be the case), since there is considerably more soft tissue and blood in these areas than in the tibial midshaft. Clearance of $\mathrm{Sr}^{85}$ from these soft tissues, being more rapid than from bone, may account for a goodly part of this rapid decline in total activity detected by the monitoring instrument.

Excretion Measurements: Although measurements of the daily output of a radioactive tracer in the urine and stool can provide very accurate information on the retention in the body, the cost in time, effort, and money is usually prohibitive. One patient (F.H.) with multiple myeloma, who was maintained in the Metabolic Ward for other purposes, was available for three $\mathrm{Sr}^{85}$ studies during his course of treatment. In each case, excretion in urine and stool was followed for at least 30 days after administration of the radioisotope. One very useful way of handling such data is to plot, for each sample, the logarithm of the 24-hour output against the logarithm of the number of days since administration of the isotope, starting with day one $(12,13)$ The experimental points lie in such a way that a fairly straight line can be drawn through them. The slope of this line can easily be computed and used to describe the steepness of the excretion curve or for comparisons of the rapidity of removal of the isotope from the body Table III summarizes the urinary excretion data for this patient. It should be noted that in all three tests the negative values for $b$ (the 
slope of the excretion curve) were greater than values reported for two normal humans accideritally exposed to $\mathrm{Sr}^{90}$ (14) This implies that $F_{\circ} H_{\circ}$ was not retaining strontium as efficiently as the normals and is in accord with the observed condition of negative calcium balance, a characteristic of this disease.

Accretion Rate: The fund of information concerning the behavior of various isotopes of strontium and calcium in the human body is growing rapidly。 The comparative studies of $\mathrm{Ca}^{45}$ and $\mathrm{Sr}^{85}$ in humans, carried out by the late Dr. Daniel Laszlo and his colleagues, deserve special mention because of their fundamental value. Perhaps the most stimulating suggestions for interpreting metabolic data on bone-seeking radioactive tracers have come from the work of Bauer, Carlsson and Lindquist. They have developed a mathematical relationship between observations of urinary excretion, fecal excretion, and serum concentrations - by means of which, numerical values can be derived for the rate of calcium accretion and the amount of readily exchangeable calcium in the skeleton。 ${ }^{(16)}$ Although several of the assumptions necessary for arriving at the final formulation have not been subjected to rigorous testing by experiment, this method of using excretion data is of great practical value. Table IV presents the calcium accretion rates for two patients, one of whom (R. B。) was receiving treatment fol: osteoporosis $\mathrm{H}, \mathrm{C}$. was hospitalized during 
healing of a rib subject to recurring fractures. The accretion rate and exchangeable bone calcium are in the normal range for $\mathrm{H} . \mathrm{C}$. , whereas the low accretion rate for $R$. B. is the same as that of one osteoporotic patient reported by Bauer, et. al.

\section{SUMMARY}

Radioactive strontium can serve as a tracer to gain information concerning calcium metabolism in human subjects. Gamma-emitting $\mathrm{Sr}^{85}$ is used rather than the much more hazardous, beta-emitting $\mathrm{Sr}^{89}$ and $\mathrm{Sr}^{90}$. $\left(\mathrm{Ca}^{47}\right.$ - the ideal tracer for normal calcium - is quite expensive and difficult to procure.) Very significant information may be obtained merely by measuring and recording the changes in radioactivity in various body areas during the first hour after intravenous injection of the bone-seeking radioisotope. This is accomplished by placing a lead-shielded gamma-scintillation detector in contact with the skin over the sites of interest and recording the activities on a scaler or ratemeter. The activity versus time curves so obtained are called radioisotope osteograms. Data were presented which indicated that $\mathrm{Sr}^{85}$ osteograms for patients afflicted with osteoporosis, Paget's disease, tumor metastases to bone, and possibly multiple myeloma, differ significantly from those obtained from subjects with no skeletal abnormalities. Some interpretations of these deviations were discussed. The value of conducting double-tracer tests (e. $\mathrm{g}_{\circ}-\mathrm{Sr}^{85}$ plus radio- 
iodinated serum albumin) was demonstrated and correlations with excretion data were milde. With further refinements the technique may ultimately become useful for certain diagnostic problems in the clinic and for evaluating the efficacy of treatment of these disorders.

\section{ACKNOWLEDGEMENTS}

The author wishes to acknowledge the generous aid given by Dr. Delores Johnson of the Harbor General Hospital of Los Angeles County in making available the facilities of the Radioisotope Division, and by Dr. Alton Eastwrood who assisted in obtaining suitable subjects and in conducting several of the individual tests. Thanks are due also to $\mathrm{Dr}$ 。W.S.Adams and Dr。W.Skoog of the Department of Medicine and to Dr.M. R. Urist of the Department of Surgery (Orthopedics) of the University of Calif ornia Medical School at Los Angeles, for arranging for studies on several of their patients in the Metabolic Ward; to Dr。L。R E Eennett and Dr。R $。$. Libby, both of the Department of Radiology, for the use of counting equipment, the donation of RISA and the preparation of injectable solutions of $\mathrm{Sr}^{85}$; and to Dr。G。V. Taplin of the Department of Nuclear Medicine and Radiation Biology for many stimulating discussions. Valuable technical assistance in the radioassay of excreta samples was rendered by Mrs。M。Hepler and Miss E. Brooks。 
TABLE I

Accumulation of $\mathrm{Sr}^{85}$ in Bone Areas

\begin{tabular}{|c|c|c|c|c|c|c|c|}
\hline \multirow[t]{2}{*}{ Subject } & \multirow[t]{2}{*}{ Skeletal Involvement } & \multicolumn{2}{|c|}{ Tibia Midshaft } & \multicolumn{2}{|c|}{ Knee } & \multicolumn{2}{|c|}{ Temple } \\
\hline & & $T_{\max }$ & A & $T_{\max }$ & $\bar{A}$ & $T_{\max }$ & $\bar{A}$ \\
\hline $\begin{array}{l}H-4 \\
H-5 \\
H-7 \\
H-13 \\
H-18 \\
H-19 \\
\end{array}$ & None (Normals) & $\begin{array}{l}20 \\
15 \\
35 \\
25 \\
15 \\
20 \\
\end{array}$ & $\begin{array}{l}0.8 \\
0.5 \\
- \\
- \\
- \\
0.8 \\
\end{array}$ & $\begin{array}{l}>40 \\
>30 \\
>60 \\
>53 \\
>45 \\
>40 \\
\end{array}$ & $\begin{array}{c}1.7 \\
0.7 \\
- \\
- \\
1.7\end{array}$ & $\begin{array}{r}- \\
13 \\
12 \\
9 \\
5 \\
5 \\
\end{array}$ & $\begin{array}{l}0.9 \\
- \\
- \\
1.0\end{array}$ \\
\hline $\mathrm{H}-20$ & Paget's Disease & $\begin{aligned} & 10 \mathrm{rt} \\
> & 45 \mathrm{lt}\end{aligned}$ & $\begin{array}{l}1.3 \\
2.3\end{array}$ & $>45$ & 3.5 & 15 & 1.1 \\
\hline $\begin{array}{l}\mathrm{H}-10 \\
\mathrm{H}-12 \\
\mathrm{H}-14 \\
\mathrm{H}-15 \\
\mathrm{H}-16\end{array}$ & $\begin{array}{l}\text { Osteoporosis } \\
\qquad \begin{array}{l}\text { Age }>70 \mathrm{yr} \\
\text { Age } 30 \mathrm{yr}\end{array}\end{array}$ & $\begin{array}{l}>35 \\
>35 \\
>60 * \\
>40 \\
45\end{array}$ & $\begin{array}{l}- \\
- \\
- \\
-\end{array}$ & $\begin{array}{l}>35 \\
>35 \\
>60 \\
>40 \\
>60\end{array}$ & $\begin{array}{l}- \\
- \\
-\end{array}$ & $\begin{array}{c}- \\
5 \\
>60^{*} \\
22 \\
15\end{array}$ & $\begin{array}{l}- \\
- \\
- \\
-\end{array}$ \\
\hline $\mathrm{H}-17$ & $\begin{array}{l}\text { Healing hip fracture } \\
\text { with osteoporosis? }\end{array}$ & 15 & 1.6 & - & - & 5 & 1.9 \\
\hline M-2 & $\begin{array}{c}\text { Multiple myeloma } \\
\text { Osteogram \#2 } \\
\text { Osteogram \#3 }\end{array}$ & $\begin{array}{r}30 \\
>45\end{array}$ & $\begin{array}{l}1.0 \\
1.0\end{array}$ & $\begin{array}{l}>60 \\
>60\end{array}$ & $\begin{array}{l}1.8 \\
1.1\end{array}$ & $\begin{array}{r}12 * * \\
5 * * \\
\end{array}$ & $\begin{array}{l}2.2 \\
1.3\end{array}$ \\
\hline $\mathrm{H}-21$ & Post-hypocalcemia & 32 & 1.6 & $>60$ & 1.8 & 15 & 1.2 \\
\hline
\end{tabular}

$\mathrm{A}=$ accumulation index $=\left(\mathrm{Sr}^{85} / \mathrm{RISA}\right)$ bone $\div\left(\mathrm{Sr}^{85} / \mathrm{RISA}\right)$ dose, at 1 hour after RISA injection.

$\mathrm{T}_{\text {max }}=$ minutes after $\mathrm{Sr}^{85}$ injection when maximum counts per minute was reached。

* Attributed to faulty injection - some $\mathrm{Sr}^{85}$ subcutaneous at point of injection.

** Activity declined slowly after reaching maximum level。 
TABLE II

Maximun $\mathrm{Sr}^{85}$ Activity of Body Site Relative

To Right Tibia Midshaft as 1.0 at 30-45 Minutes After $\mathrm{Sr}^{85}$ Injection

\begin{tabular}{|l|c|c|c|c|}
\hline Subject & Skeletal Involvement & Knee & $\begin{array}{c}\text { Lumbar } \\
\text { Spine }\end{array}$ & Temple \\
\hline \hline H-4 & & 1.9 & - & - \\
H-5 & & 1.1 & 4.1 & 1.7 \\
H-7 & None (Normalis) & 1.6 & 4.0 & 2.8 \\
H-13 & & 1.7 & 4.9 & 2.1 \\
H-18 & & 1.8 & 7.6 & 3.0 \\
H-19 & & 2.3 & - & 2.9 \\
\hline & Paget's Disea $: 3 e$ & $1.4(\mathrm{rt})$ & 3.5 & 1.8 \\
H-20 & right tibia $:=1.0$ & $2.3(1 \mathrm{t})$ & - & - \\
& left tibia $=2.5$ & 2.3 & - & - \\
H-10 & Osteoporosis & 1.5 & 7.3 & 3.0 \\
H-12 & & 1.7 & - & 3.5 \\
H-14 & Age >70 y: & 1.6 & - & 2.1 \\
H-15 & & 1.4 & 4.9 & 2.0 \\
H-16 & Age 30 yr & 1.4 & 8.3 & 2.6 \\
\hline H-17 & Fracture, hip & 1.5 & 8.0 & 2.2 \\
\hline M-2 & Multiple Myelioma & 1.2 & - & 1.6 \\
& & & & \\
\hline
\end{tabular}


TABLE III

Urinary Excretion of Radiostrontium

\begin{tabular}{|llccl|}
\hline Isotope & Patient & $\mathrm{a}$ & $\mathrm{b}$ & Condition, Treatment \\
\hline $\mathrm{Sr}^{85}$ & F. H. Test \#1 & 28.6 & -1.7 & $\begin{array}{c}\text { Multiple myeloma } \\
\text { (prednisone) }\end{array}$ \\
$\mathrm{Sr}^{85}$ & F。H. Test \#2 & 20.0 & -1.5 & $\begin{array}{c}\text { (prednisone and } \\
\text { testosterone) }\end{array}$ \\
$\mathrm{Sr}^{85}$ & F。H.Test \#3 & 18.5 & -1.4 & $\begin{array}{l}\text { (testosterone and ACTH) } \\
\mathrm{Sr}^{90}\end{array}$ \\
$\mathrm{Sr}^{90}$ & $50 \mathrm{yr}$ old male & & -1.1 & Normal* \\
\hline
\end{tabular}

$$
\begin{aligned}
& \mathbf{E}=a \mathrm{t}^{-\mathrm{b}} \text {, where } \mathbf{E}=\% \text { of dose excreted per day, } \\
& t=\text { time, in days, after injection } \\
& \mathrm{b}=\text { slope of the line when } \mathrm{E} \text { and } \mathrm{t} \text { are } \\
& \text { plotted on log-log coordinate paper } \\
& \mathrm{a}=\text { intercept on the } \mathbf{E} \text { axis; corresponds } \\
& \text { to the \% excreted during day } 1
\end{aligned}
$$

* Reported by Stewart, et. al. (12) 


\section{TABLE IV}

Excretion of $\mathrm{Sr}^{85}$ and Calculated Calcium Accretion Rates

\begin{tabular}{|llccc|}
\hline Patient & Diagnosis & $\begin{array}{l}\text { \% of Dose of Sr85 } \\
\text { in. urine and stool } \\
\text { during first 5 days } \\
\text { after injection }\end{array}$ & $\begin{array}{c}\text { Accretion Rate* } \\
\text { (gms Ca per day) }\end{array}$ & $\begin{array}{c}\text { Exchangeable } \\
\text { Bone Calcium* } \\
\text { (gms) }\end{array}$ \\
\hline \hline R.B. & $\begin{array}{l}\text { Osteoporosis } \\
\text { H.C. }\end{array}$ & 70.0 & 0.19 & 2.7 \\
\hline $\begin{array}{l}\text { (?) Possible } \\
\text { osteoporosis } \\
\text { or osteomalacia }\end{array}$ & 42.4 & 0.72 & 4.8 \\
\hline
\end{tabular}

* Calculated from dajly excreta and serum levels of $\mathrm{Sr}^{85}$ using the method of Baue1, Carlsson, and Lindquist. 


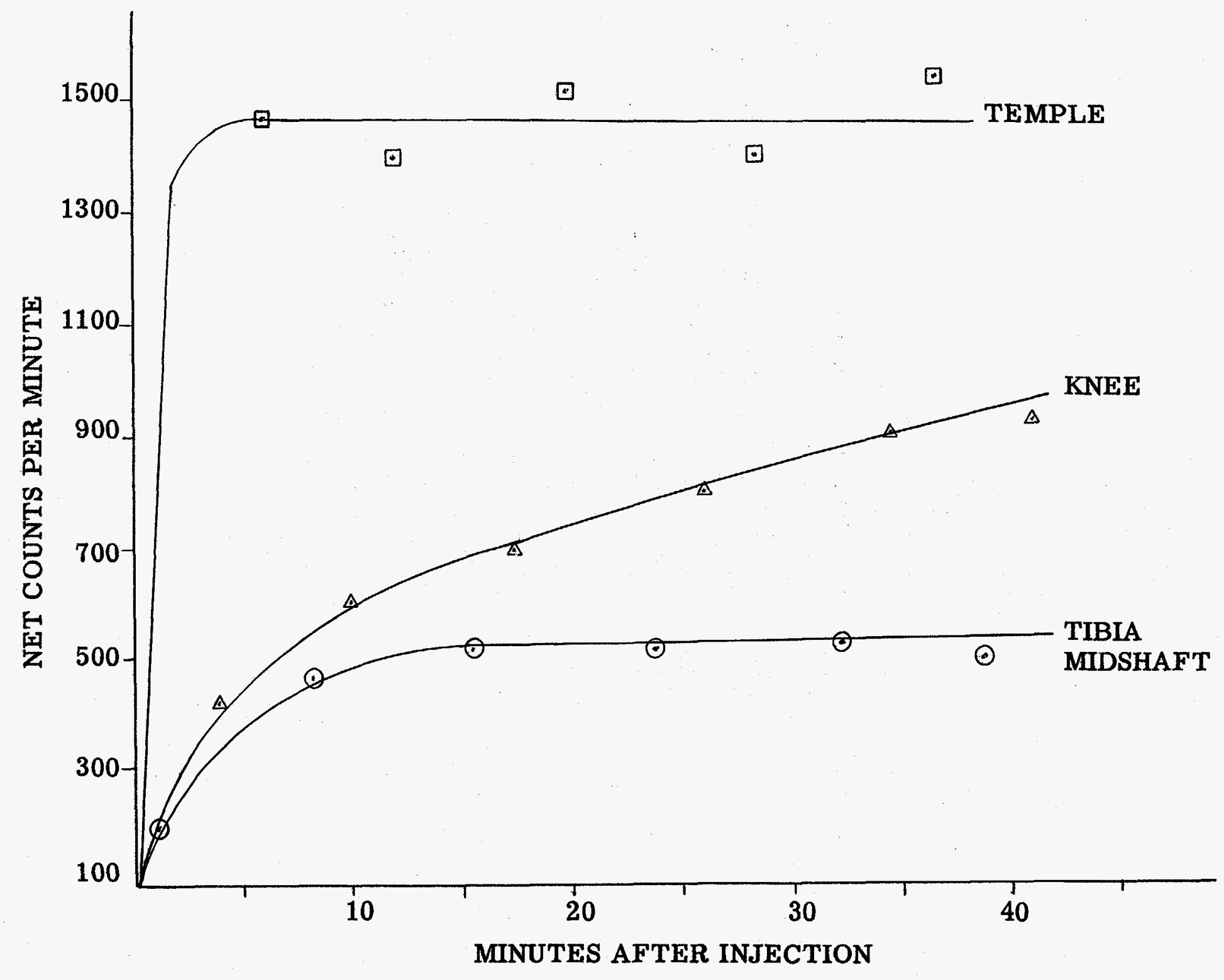

Fig. $1 \quad \mathrm{Sr}^{85}$ Osteogram -- 24 year old female with no skeletal abnormalities 


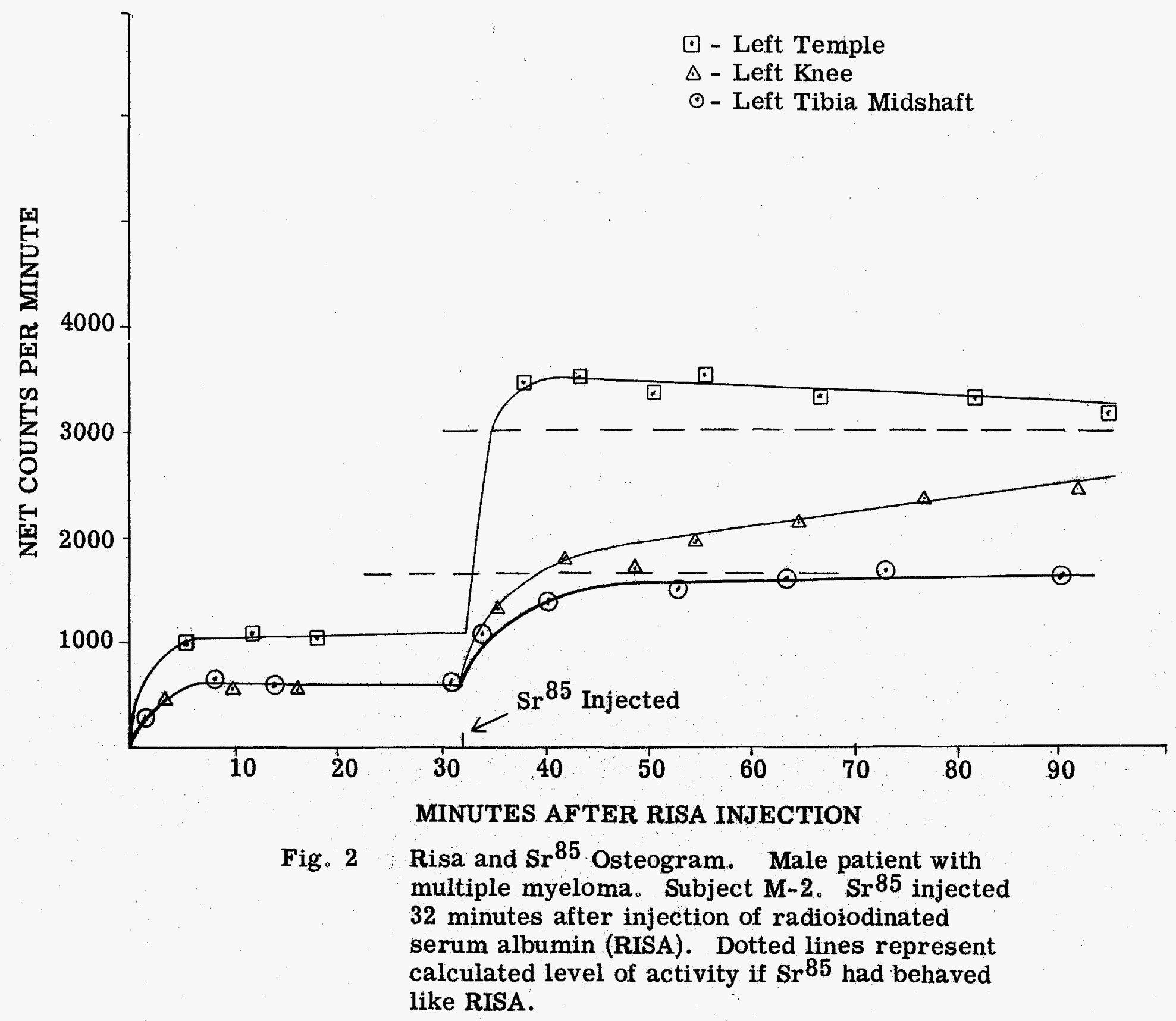




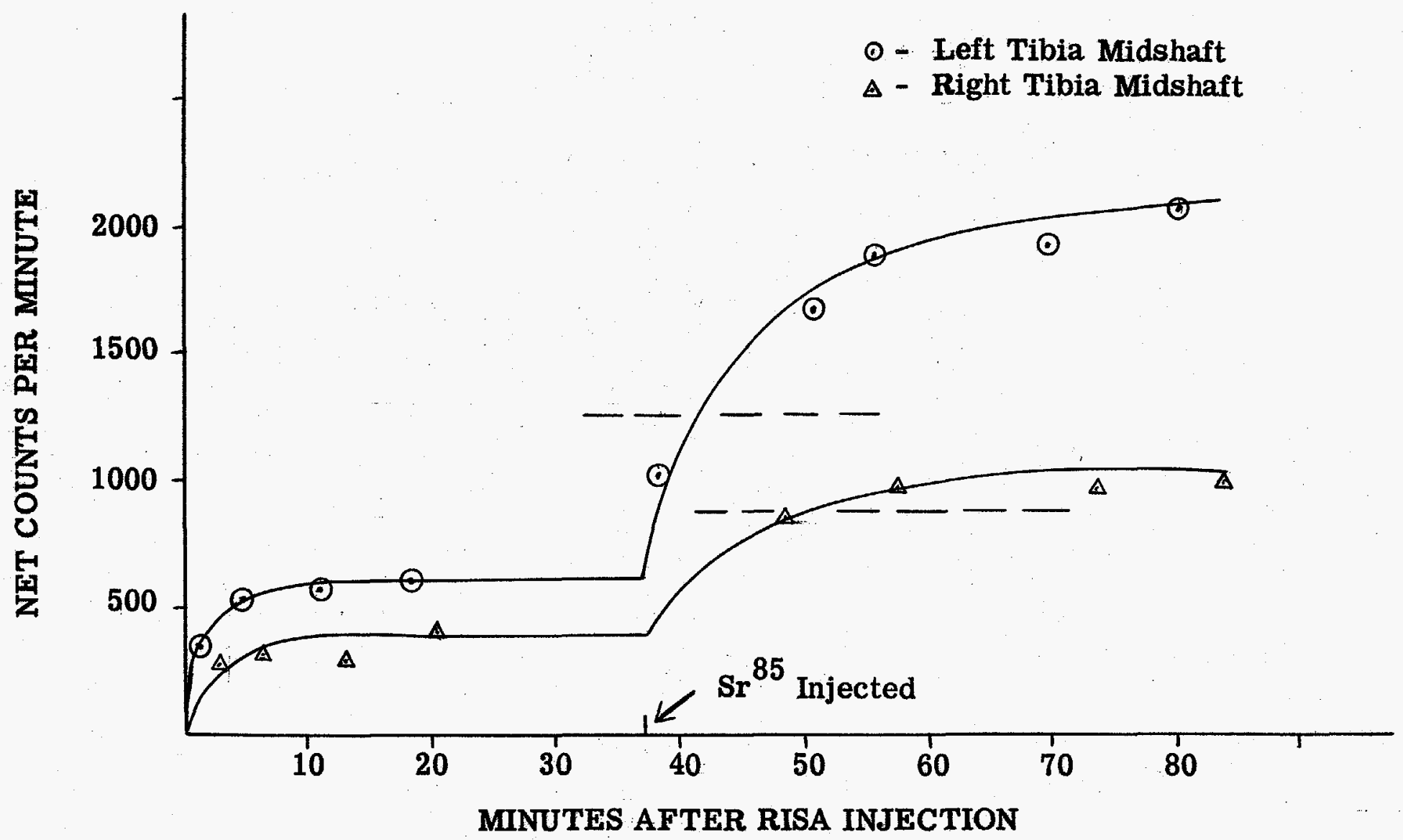

Fig. 3 Risa and $\mathrm{Sr}^{85}$ Osteogram. 46 year old female with Paget's disease. Left tibia bowed and hyperemic。 $\mathrm{Sr}^{85}$ injected 37 minutes after injection of radioiodinated serum albumin (RISA). Dotted lines represent calculated net activity, if $\mathbf{S r} 85$ were to behave like RISA. 


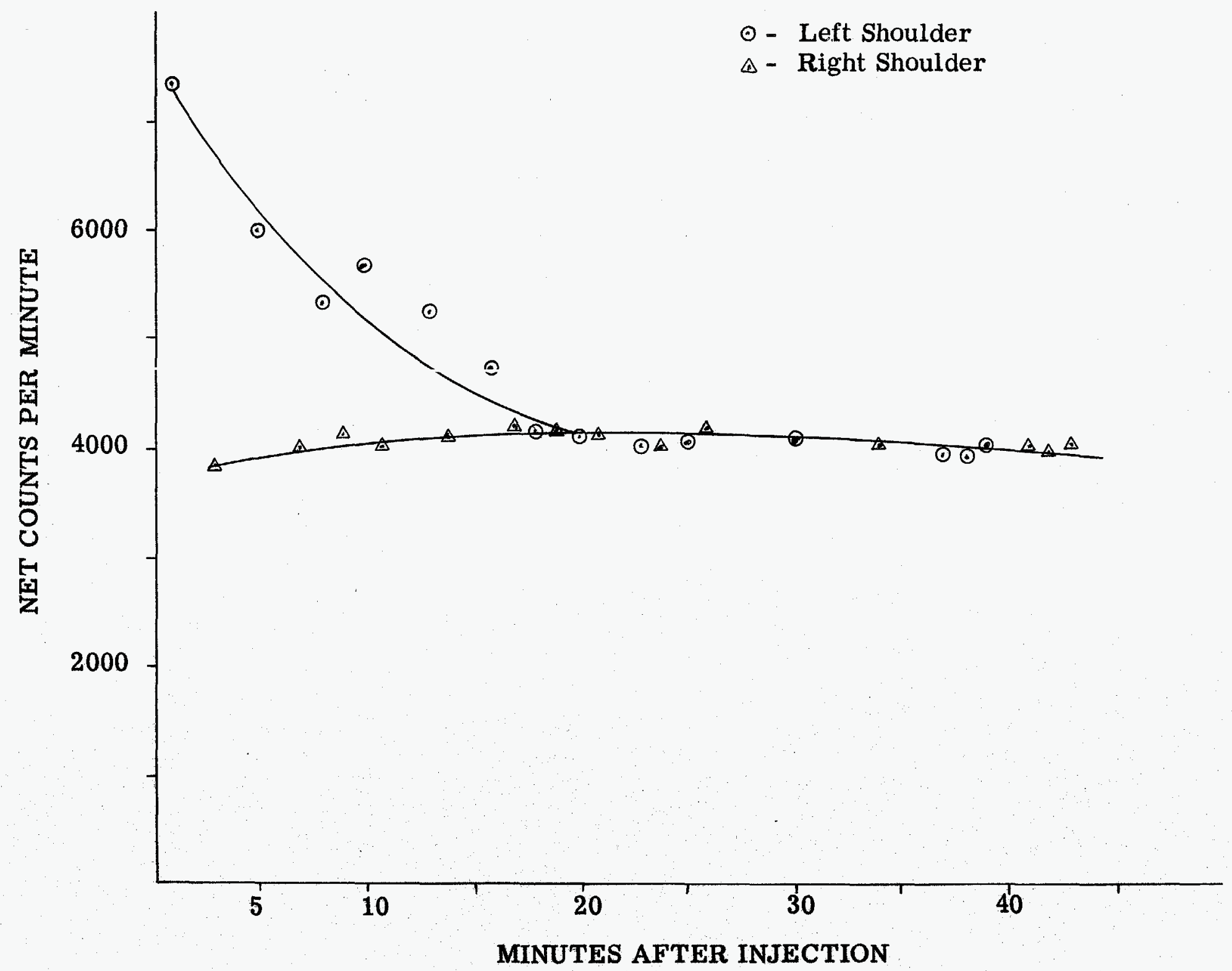

Fig. $4 \quad \mathrm{Sr}^{85}$ Osteogram -- 42 year old female with calcified lesion near head of right humerus. 


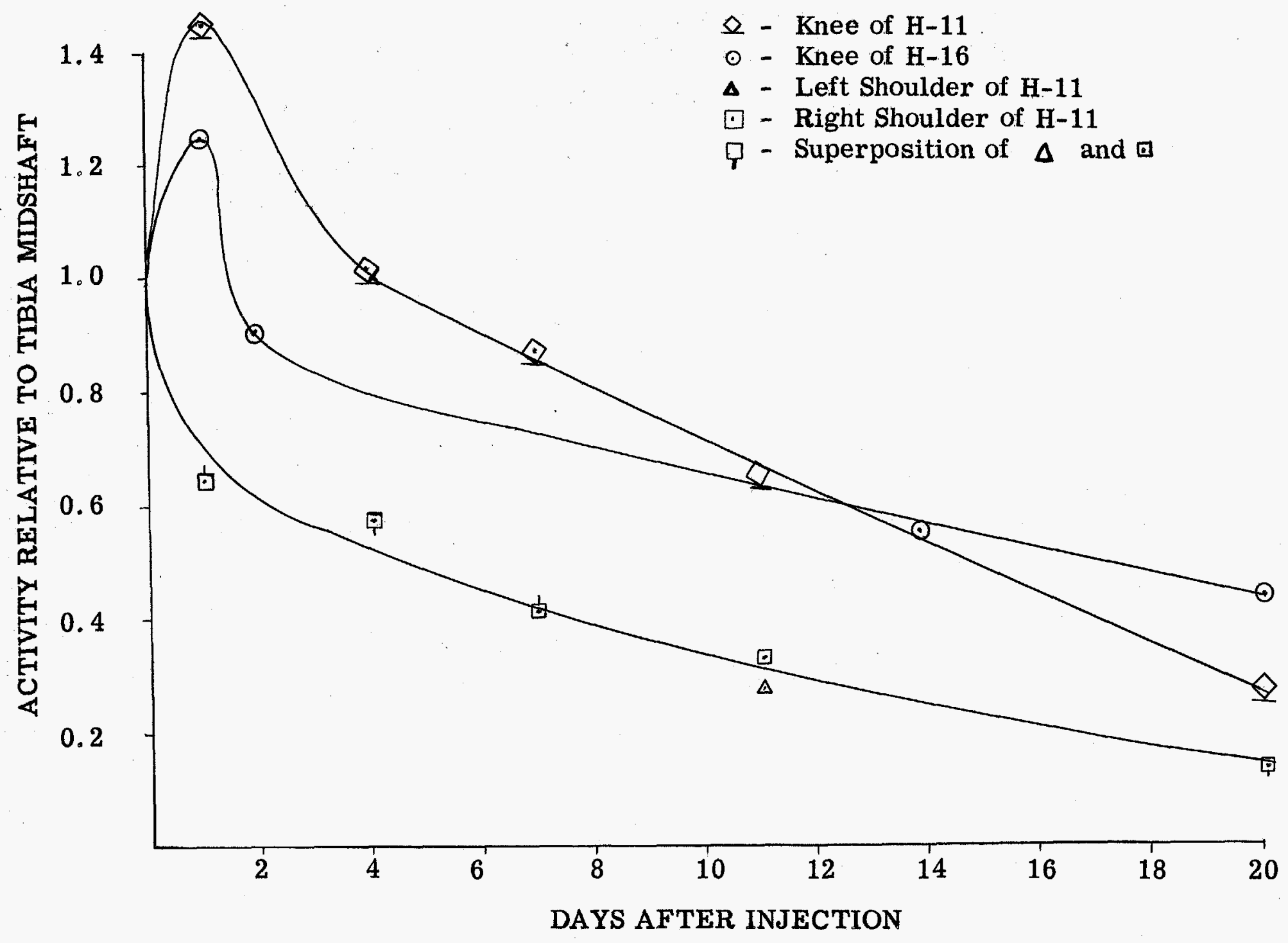

Fig. 5

Monitoring of Areas After Injection of $\mathrm{Sr}^{85}$.

$\mathrm{H}-11$ had a calcified lesion near head of right humerus and metastases from a breast tumor. H-16 had osteoporosis. 


\section{REFERENCES}

1. MacDonald, N. S., Noyes, P., and Lorick, P. C.: Discrimination of Calcium and Strontium by the Kidney. Am. J. Physiol. 188:131, 1957.

2. Comar, C. L., Wasiserman, R. H., Ullberg, S. and Andrews, G. A. : Strontium Metabolism and Strontium-Calcium Discrimination. Proc. Soc. Exper. Biol。 and Med., 95:386, 1957.

3. Schulert, A。 R., Płets, E. A., Laszlo, D., Spencer, $H_{\circ}$, Charles, M., and Samachson, J.: Comparative Metabolism of Strontium and Calcium in Man. Int. J. Applied Rad. and Isotopes, $4: 144,1959$.

4. Alexander, G. V. and Nusbaum, R. E.: The Relative Retention of Strontium and Calcium in Human Bone Tissue. J. Biol. Chem., 234:418, 1959 .

5. Bauer, G. C. H.: Skeletal Metabolism in Humans Studied with Body Surface Counting of $\mathrm{Sr}^{85}$ and $\mathrm{Ca} 47$. International Conf. on Radioisotopes in Scientific Research, UNESCO/NS/RIC/144, 1957.

6. Bauer, G. C. H. and Ray, R. D.: Kinetics of Strontium Metabolism in Man. J. Bone and Joint Surg., 40A:171, 1958.

7. MacDonald, N. S.: Kinetic Studies of Skeletal Metabolism by External Counting of Injected Radioisotopes. J. Lab. and Clin. Med., 52:541, 1958 .

8. Neuman, W. F., and Neuman, M. W.: The Chemical Dynamics of Bone Mineral. p. 55, Chicago, University of Chicago Press, 1958.

9. Jones, D. C. and Copp, D. H.: The Metabolism of Radioactive Strontium in Adult, Young and Rachitic Rats. J. Biol. Chem., 189:509, 1951 .

10. MacDonald, N. S., Nusbaum, R. E., Ezmirlian, F., Barbera, R. C., Spain, P. and Rounds, D. E.: Mechanisms in Skeletal Accumulation of Ions. Arch. Biochemistry and Biophysics, $43: 118,1953$. 
11. Bauer, G. C. H., Carlsson, A., and Lindquist, B.: Use of Isotopes in Clinical Studies of Skeletal Metabolism in Radioactive Isotope in Klinik and Forschung, vol. 3, p. 25, München, Urban und Schwargenberg, 1958.

12. Norris, W. P., Tyler, S. A., and Brues, A. M.: Retention of Radioactive Bone-Seekers. Science, 128:456, 1958.

13. Langham, W. H.: Excretion Methods. Brit. J. Radiology, Supplement, 7:95, 1957.

14. Stewart, C. G., Vogt, E., Hitchman, A. J. W., and Jupe, N.: On the Excretion of $\mathrm{Sr}^{90}$ and $\mathrm{Cs}^{137}$ by the Human. Second United Nations Int. Conf. on Peaceful Uses of Atomic Eneegy. Paper A/Conf. 15/P/220, 1958.

15. Laszlo, D. and Spencer, H.: Radiostrontium Metabolism and Decontamination in Man. Second Int. Conf. on Peaceful Uses of Atomic Energy. Paper A/Conf, 15/P/1008, 1958.

16. Bauer, G. C. H., Carlsson, A., and Lindquist, B.: Evaluation of Accretion, Resorption, and Exchange Reactions in the Skeleton. Kurgl. Fysiografiska Sällskapets I Lund Forhandlingar, 25:No. 1, 1955. 